\title{
Treatment of Anthrax Disease Frequently Asked Questions
}

KS Judd

JK Young

AM Lesperance, MSPH

JD Malone, MD, MPH

May 14,2010

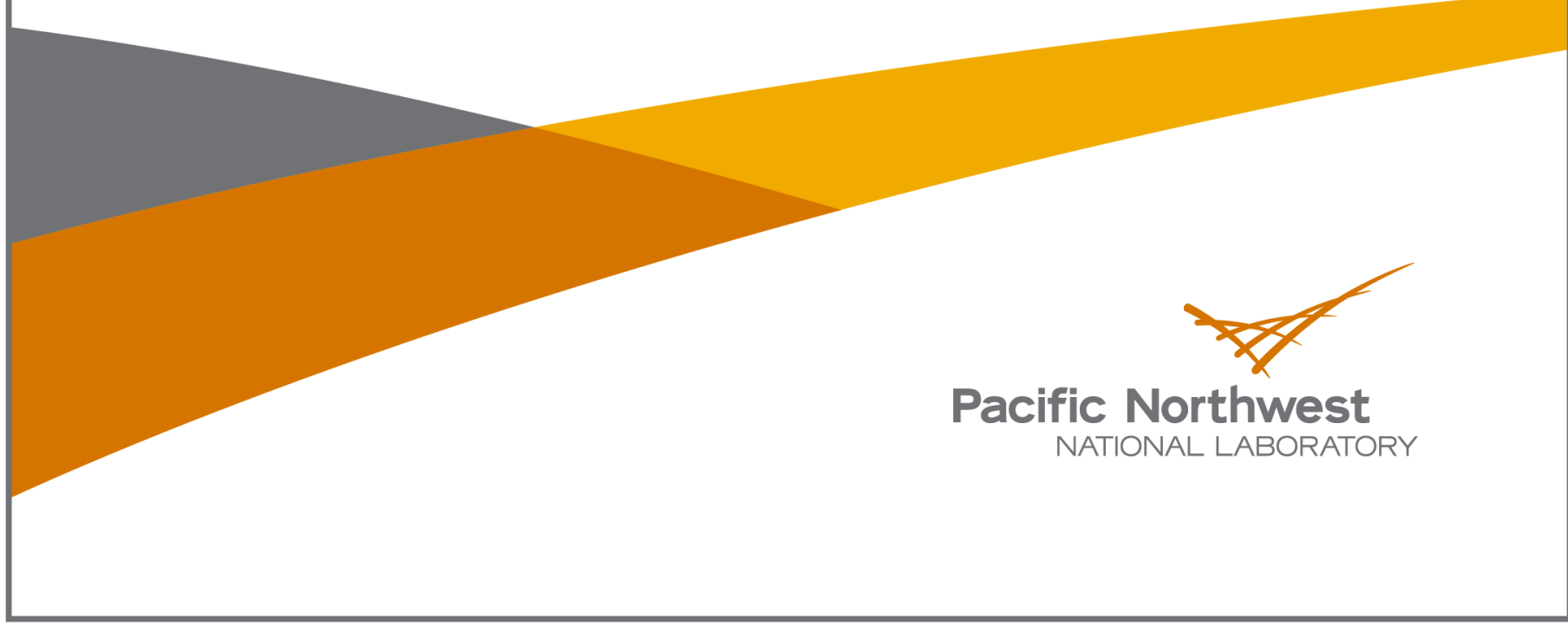




\title{
DISCLAIMER
}

This report was prepared as an account of work sponsored by an agency of the United States Government. Neither the United States Government nor any agency thereof, nor Battelle Memorial Institute, nor any of their employees, makes any warranty, express or implied, or assumes any legal liability or responsibility for the accuracy, completeness, or usefulness of any information, apparatus, product, or process disclosed, or represents that its use would not infringe privately owned rights. Reference herein to any specific commercial product, process, or service by trade name, trademark, manufacturer, or otherwise does not necessarily constitute or imply its endorsement, recommendation, or favoring by the United States Government or any agency thereof, or Battelle Memorial Institute. The views and opinions of authors expressed herein do not necessarily state or reflect those of the United States Government or any agency thereof.

\author{
PACIFIC NORTHWEST NATIONAL LABORATORY \\ operated by \\ BATTELLE \\ for the \\ UNITED STATES DEPARTMENT OF ENERGY \\ under Contract DE-AC05-76RL01830
}

Printed in the United States of America
Available to DOE and DOE contractors from the Office of Scientific and Technical Information,
P.O. Box 62, Oak Ridge, TN 37831-0062;
ph: (865) 576-8401
fax: $(865) 576-5728$
email: reports@adonis.osti.gov

\footnotetext{
Available to the public from the National Technical Information Service, U.S. Department of Commerce, 5285 Port Royal Rd., Springfield, VA 22161 ph: (800) 553-6847 fax: $(703) 605-6900$

email: orders@ntis.fedworld.gov

online ordering: http://www.ntis.gov/ordering.htm
} 


\section{TABLE OF CONTENTS}

INTRODUCTION

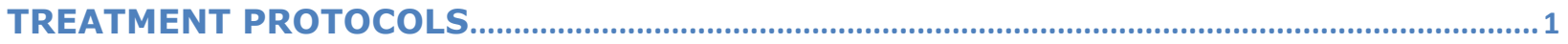

WHAT TREATMENT IS RECOMMENDED FOR INDIVIDUALS POTENTIALLY EXPOSED TO ANTHRAX? ...................... 1

WHAT ANTIBIOTICS ARE KNOWN TO BE EFFECTIVE FOR PREVENTION AND TREATMENT OF INHALATION

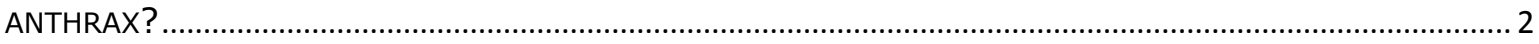

WHAT ARE THE RECOMMENDED ANTIBIOTIC DOSAGES FOR ANTHRAX TREATMENT? ....................................... 3

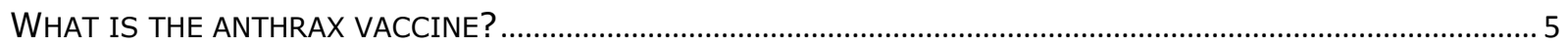

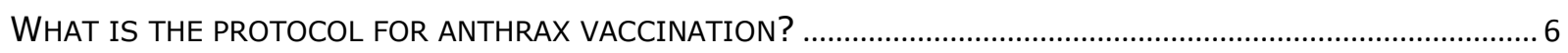

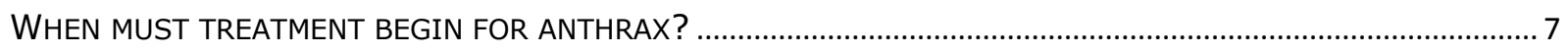

WHY ARE 60 DAYS OF ANTIBIOTIC TREATMENT RECOMMENDED? ............................................................ 7

SHOULD CHILDREN BE OFFERED ANTIBIOTICS AND VACCINATION IF ANTHRAX EXPOSURE IS SUSPECTED?.... 8

SHOULD IMMUNOCOMPROMISED PERSONS RECEIVE ANTIBIOTICS AND VACCINATION IF ANTHRAX EXPOSURE

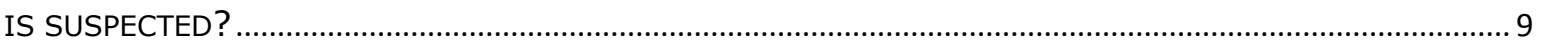

SHOULD PREGNANT OR BREASTFEEDING WOMEN RECEIVE ANTIBIOTICS AND VACCINATION IF ANTHRAX

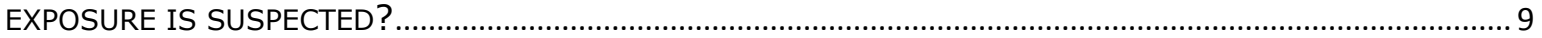

SHOULD INDIVIDUALS THAT HAVE RECEIVED THE ANTHRAX VACCINE PRIOR TO POTENTIAL EXPOSURE BE TREATED WITH ORAL ANTIBIOTICS? .................................................................................................. 11

WHO SHOULD GET ANTHRAX VACCINE PRIOR TO EXPOSURE? ......................................................................... 11

SHOULD FIRST RESPONDERS BE VACCINATED FOR BIOTERRORISM PREPAREDNESS? ................................... 12

ARE THERE ANY PROMISING NEW TREATMENTS FOR ANTHRAX DISEASE UNDER DEVELOPMENT? .................... 12

EFFICACY OF RECOMMENDED MEDICATIONS ............................................................................. 14

HOW EFFECTIVE IS THE RECOMMENDED COMBINED ANTIBIOTIC-VACCINE TREATMENT? ................................ 14

HOW EFFECTIVE IS ANTIBIOTIC-ONLY TREATMENT FOR ANTHRAX? ............................................................. 14

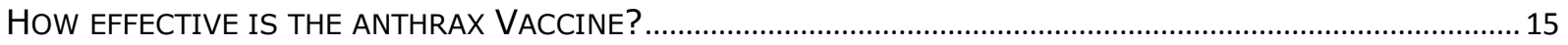


HOW SAFE IS IT TO TAKE THESE ANTIBIOTICS FOR LONG PERIODS OF TIME?....

WHAT ADVERSE REACTIONS ARE ASSOCIATED WITH THE RECOMMENDED ANTIBIOTICS?

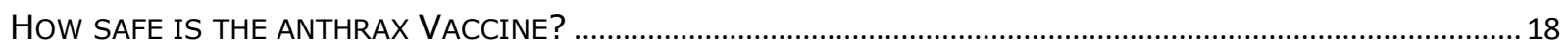

WHAT SIDE EFFECTS ARE ASSOCIATED WITH THE ANTHRAX VACCINE? ............................................................ 18

WHAT IS TREATMENT IS ADVISED FOR INDIVIDUALS WHO HAVE HAD ADVERSE REACTIONS TO THE RECOMMENDED DRUGS?

IS THE ANTHRAX VACCINE SAFE FOR CHILDREN, THE ELDERLY, PREGNANT WOMEN, AND THE IMMUNOCOMPROMISED? 


\section{TREATMENT OF ANTHRAX DISEASE FREQUENTLY ASKED QUESTIONS}

\section{INTRODUCTION}

This document provides a summary of Frequently Asked Questions (FAQs) on the treatment of anthrax disease caused by a wide-area release of Bacillus anthracis spores as an act of bioterrorism. These FAQs are intended to provide the public health and medical community, as well as others, with guidance and communications to support the response and long-term recovery from an anthrax event.

The FAQs and answers were drawn from the following: a review of the primary public sources of health information for anthrax disease, including the Centers for Disease Control and Prevention (CDC), National Institutes of Health (NIH), and the Food and Drug Administration (FDA); public health and medical conference presentations and literature; and discussions with subject matter experts.

FAQs and answers are organized around the following three topics:

1) treatment protocols

2) efficacy of recommended medications

3) safety and potential adverse reactions to medication

These FAQs were developed by Pacific Northwest National Laboratory for the Defense Threat Reduction Agency (DTRA) in support of the Interagency Biological Restoration Demonstration (IBRD). IBRD is a joint project of the Department of Defense (DOD)'s DTRA and the Department of Homeland Security, which is being conducted in the Seattle Urban Area and at Fort Lewis Military Base. This program will develop a blueprint for the recovery and restoration of large urban areas and DOD installations in the event of aerosol release of a biological agent.

\section{TREATMENT PROTOCOLS}

WHAT TREATMENT IS RECOMMENDED FOR INDIVIDUALS POTENTIALLY EXPOSED TO ANTHRAX?

The recommended protocol for protection against anthrax disease after potential exposure to aerosolized anthrax spores is 60 days of selected antibiotics in combination with 6-doses of anthrax vaccine. Ciprofloxacin, doxycycline, or levofloxacin are antibiotics approved by the FDA for prevention and treatment of bioterrorism-related anthrax in adults, pregnant women, and children. Additional guidance exists for use of the medications in pregnancy and children. 
For individuals who have known exposure to anthrax but have no signs and symptoms of the disease, oral antibiotics should be taken with the vaccine. Ciprofloxacin and doxycycline are both recommend as the first line of defense. While Levofloxacin is FDA-approved for treatment of anthrax, there is less experience with the drug compared with ciprofloxacin and doxycycline.

If individuals are showing symptoms of inhalational anthrax, an intravenous multiple-drug regimen of ciprofloxacin or doxycycline and one or two other antimicrobials is recommended.

This treatment protocol was recommended by three major U.S. national advisory bodies: the Advisory Committee on Immunization Practices (ACIP) (CDC 2002), the John Hopkins Working Group on Civilian Biodefense (Inglesby 2002), and the Institute of Medicine (IOM 2001). The same recommendations for post-exposure protection were reiterated by the CDC at the June 2008 ACIP meeting.

\section{REFERENCES}

CDC. Use of Anthrax vaccine in response to terrorism: supplemental recommendations of the Advisory Committee on Immunization Practices (ACIP). MMWR. 2002;51(45):1024-6.

CDC. Minutes of June 2008 ACIP meeting. Available at: http://www.cdc.gov/vaccines/recs/acip/downloads/minjun08.pdf.

Inglesby TV, O'Toole T, Henderson DA, et al, for the John Hopkins Working Group on Civilian Biodefense. Anthrax as a biological weapon: updated recommendations for management. JAMA. 2002;287(17):2236-52.

Institute of Medicine. Review of the Anthrax Vaccine Safety \& Efficacy Research Program: Interim Report. Washington, D.C.: National Academy Press; 2001.

\section{WHAT ANTIBIOTICS ARE KNOWN TO BE EFFECTIVE FOR PREVENTION AND TREATMENT OF INHALATION ANTHRAX?}

Ciprofloxacin, doxycycline, or levofloxacin are antibiotics approved by the FDA for prevention and treatment of bioterrorism-related anthrax in adults, pregnant women, and children. Ciprofloxacin and doxycycline are both recommend as the first line of defense. Doxycycline may be less optimal if the patient has or is suspected of having meningitis because of poor central nervous system penetration. While Levofloxacin is FDA-approved for treatment of anthrax, there is less experience with this drug as compared with ciprofloxacin and doxycycline, especially with use over 28 days.

If individuals are showing symptoms of inhalational anthrax, an intravenous multiple-drug regimen of ciprofloxacin or doxycycline and 1 or 2 other antimicrobials is recommended.

Penicillins are not recommended as initial therapy for bioterrorism-related anthrax. If laboratory tests confirm that the specific strain of Bacillus anthracis is sensitive to the penicillin class of antibiotics (e.g. amoxicillin, ampicillin), while not FDA-approved, these drugs are safe and appropriately prescribed by a physician. 
If first-line drugs are not available (e.g. supply or logistic problems because large numbers of individuals require treatment in a mass casualty setting), other fluoroquinolones (e.g. gatifloxacin, moxifloxacin, ofloxacin) are acceptable alternatives. These fluoroquinolones are not specifically recommended because of a lack of sufficient data on their efficacy.

Some infectious disease authorities recommended preferential use of ciprofloxacin over doxycycline, plus augmentation with chloramphenicol, rifampin, or penicillin when meningitis is established or suspected. Because antibiotic resistance can be induced relatively rapidly in vitro, close monitoring of patients treated for anthrax is important to see if alternative antibiotics should be prescribed (Athamna 2004).

\section{REFERENCES}

Athamna A, Athamna M, Abu-Rashed N, Medlej B, Bast DJ, and Rubinstein E. Selection of Bacillus anthracis isolates resistant to antibiotics. Journal of Antimicrobial Chemotherapy. 2004; 54:424-8.

FDA. Cipro (Ciprofloxacin Hydrochloride) for Inhalation Anthrax. Available at:

http://www.fda.gov/Drugs/EmergencyPreparedness/BioterrorismandDrugPreparedness/ucm130709.htm. Updated July 8, 2009. Accessed July 23, 2009.

FDA. Prescription drug products; doxycycline and penicillin G procaine administration for inhalational anthrax (post-exposure). Federal Register 2001;66:55679-82.

FDA. Levofloxacin. Approval Letter for Post-Exposure Prophylaxis in Pediatric Patients. Dated May 5, 2008.

Available at:

http://www.fda.gov/downloads/Drugs/EmergencyPreparedness/BioterrorismandDrugPreparedness/UCM133682. pdf.

FDA. Levofloxacin. Approval Letter for Post-Exposure Prophylaxis in Adults. Dated November 24, 2004. Available at: http://www.accessdata.fda.gov/drugsatfda_docs/appletter/2004/20634s035,20635s035,21721s003/tr.pdf.

Inglesby TV, O'Toole T, Henderson DA, et al. Anthrax as a Biological Weapon: Updated Recommendations for Management. JAMA. 2002;287(17):2236-52. Available at: http://jama.ama-

assn.org/cgi/content/full/287/17/2236.

Meyerhoff A, Murphy D, Tice AD, Inglesby T, and O’Toole T. Guidelines for treatment of anthrax.

JAMA.2002;288(15):1848-49.

\section{WHAT ARE THE RECOMMENDED ANTIBIOTIC DOSAGES FOR ANTHRAX TREATMENT?}

The recommended antibiotic regimens for anthrax prevention and treatment are outlined in Tables 1 and 2 below. Those patients without symptoms should be started on oral antibiotics. Those patients with cutaneous and intestinal anthrax with subtle signs or symptoms of systemic involvement should be started on a three-drug intravenous regimen for inhalational anthrax in Table 1. If intravenous ciprofloxacin is not available, oral ciprofloxacin may be acceptable because of rapid and excellent absorption from the gastrointestinal tract if vomiting or indigestion are not present. 
TABLE 1. Inhalational anthrax treatment protocol ${ }^{*,+}$ for cases associated with this bioterrorism attack

\begin{tabular}{|c|c|c|}
\hline Category & Initial therapy (intravenous) ${ }^{3,9}$ & Duration \\
\hline Adults & $\begin{array}{l}\text { Ciprofloxacin } 400 \text { mg every } 12 \mathrm{hrs}^{*} \\
\text { or } \\
\begin{array}{c}\text { Doxycycline } 100 \mathrm{mg} \text { every } 12 \mathrm{hrs}^{\dagger \dagger} \\
\text { and }\end{array} \\
\text { One or two additional antimicrobials }\end{array}$ & $\begin{array}{l}\text { IV treatment initially**. Switch to } \\
\text { oral antimicrobial therapy when } \\
\text { clinically appropriate: } \\
\text { Ciprofloxacin } 500 \mathrm{mg} \text { po BID } \\
\text { or } \\
\text { Doxycycline } 100 \mathrm{mg} \text { po BID } \\
\text { Continue for } 60 \text { days (IV and po } \\
\text { combined)" }\end{array}$ \\
\hline Children & 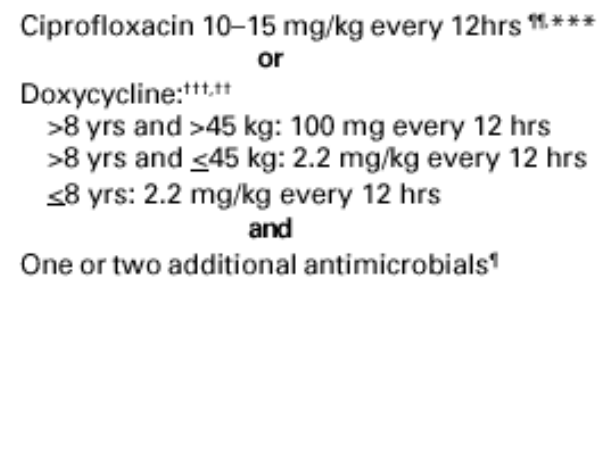 & $\begin{array}{l}\text { IV treatment initially**. Switch to } \\
\text { oral antimicrobial therapy when } \\
\text { clinically appropriate: } \\
\text { Ciprofloxacin } 10-15 \mathrm{mg} / \mathrm{kg} \text { po } \\
\text { every } 12 \mathrm{hrs} * * * \\
\text { or } \\
\text { Doxycycline: }{ }^{* t+} \\
>8 \mathrm{yrs} \text { and }>45 \mathrm{~kg}: 100 \mathrm{mg} \text { po BID } \\
>8 \mathrm{yrs} \text { and } \leq 45 \mathrm{~kg}: 2.2 \mathrm{mg} / \mathrm{kg} \text { po BID } \\
\leq 8 \mathrm{yrs:} 2.2 \mathrm{mg} / \mathrm{kg} \text { po BID } \\
\text { Continue for } 60 \text { days (IV and po } \\
\text { combined) }\end{array}$ \\
\hline Pregnant women ${ }^{514}$ & $\begin{array}{l}\text { Same for nonpregnant adults (the high } \\
\text { death rate from the infection outweighs } \\
\text { the risk posed by the antimicrobial agent) }\end{array}$ & $\begin{array}{l}\text { IV treatment initially. Switch to } \\
\text { oral antimicrobial therapy when } \\
\text { clinically appropriate. }{ }^{\dagger} \text { Oral } \\
\text { therapy regimens same for } \\
\text { nonpregnant adults }\end{array}$ \\
\hline $\begin{array}{l}\text { Immunocompromised } \\
\text { persons }\end{array}$ & $\begin{array}{l}\text { Same for nonimmunocompromised persons } \\
\text { and children }\end{array}$ & $\begin{array}{l}\text { Same for nonimmunocompromised } \\
\text { persons and children }\end{array}$ \\
\hline \multicolumn{3}{|c|}{$\begin{array}{l}\text { * For gastrointestinal and oropharyngeal anthrax, use regimens recommended for inhalational anthrax. } \\
\text { ' Ciprofloxacin or doxycycline should be considered an essential part of first-line therapy for inhalational } \\
\text { anthrax. } \\
\text { ' Steroids may be considered as an adjunct therapy for patients with severe edema and for meningitis based on } \\
\text { experience with bacterial meningitis of other etiologies. } \\
\text { ' Other agents with in vitro activity include rifampin, vancomycin, penicillin, ampicillin, chloramphenicol, } \\
\text { imipenem, clindamycin, and clarithromycin. Because of concerns of constitutive and inducible beta-lactamases } \\
\text { in Bacillus anthracis, penicillin and ampicillin should not be used alone. Consultation with an infectious disease } \\
\text { specialist is advised. } \\
\text { ** Initial therapy may be altered based on clinical course of the patient; one or two antimicrobial agents (e.g., } \\
\text { ciprofloxacin or doxycycline) may be adequate as the patient improves. } \\
\text { tt If meningitis is suspected, doxycycline may be less optimal because of poor central nervous system penetra- } \\
\text { tion. } \\
\text { " Because of the potential persistence of spores after an aerosol exposure, antimicrobial therapy should be } \\
\text { continued for } 60 \text { days. } \\
\text { " If intravenous ciprofloxacin is not available, oral ciprofloxacin may be acceptable because it is rapidly and well } \\
\text { absorbed from the gastrointestinal tract with no substantial loss by first-pass metabolism. Maximum serum } \\
\text { concentrations are attained } 1-2 \text { hours after oral dosing but may not be achieved if vomiting or ileus are present. } \\
\text { *** In children, ciprofloxacin dosage should not exceed } 1 \text { g/day. } \\
\text { tIt The American Academy of Pediatrics recommends treatment of young children with tetracyclines for serious } \\
\text { infections (e.g., Rocky Mountain spotted fever). } \\
\text { in Although tetracyclines are not recommended during pregnancy, their use may be indicated for life-threatening } \\
\text { illness. Adverse effects on developing teeth and bones are dose related; therefore, doxycycline might be used } \\
\text { for a short time (7-14 days) before } 6 \text { months of gestation. }\end{array}$} \\
\hline
\end{tabular}

Source: CDC 2001 
TABLE 2. Cutaneous anthrax treatment protocol* for cases associated with this bioterrorism attack

\begin{tabular}{|c|c|c|}
\hline Category & Initial therapy (oral) ${ }^{\dagger}$ & Duration \\
\hline Adults* & $\begin{array}{c}\text { Ciprofloxacin } 500 \mathrm{mg} \text { BID } \\
\text { or } \\
\text { Doxycycline } 100 \mathrm{mg} \mathrm{BID}\end{array}$ & 60 days $^{3}$ \\
\hline Children* & $\begin{array}{l}\text { Ciprofloxacin } 10-15 \mathrm{mg} / \mathrm{kg} \text { every } 12 \mathrm{hrs} \\
\text { (not to exceed } 1 \mathrm{~g} / \mathrm{day})^{\dagger} \\
\text { or } \\
\text { Doxycycline: } \\
>8 \text { yrs and }>45 \mathrm{~kg}: 100 \mathrm{mg} \text { every } 12 \mathrm{hrs} \\
>8 \mathrm{yrs} \text { and } \leq 45 \mathrm{~kg}: 2.2 \mathrm{mg} / \mathrm{kg} \text { every } 12 \mathrm{hrs} \\
\leq 8 \mathrm{yrs}: 2.2 \mathrm{mg} / \mathrm{kg} \text { every } 12 \mathrm{hrs}\end{array}$ & 60 days $^{3}$ \\
\hline Pregnant women**** & $\begin{array}{c}\text { Ciprofloxacin } 500 \text { mg BID } \\
\text { or } \\
\text { Doxycycline } 100 \text { mg BID }\end{array}$ & 60 days $^{3}$ \\
\hline $\begin{array}{l}\text { Immunocompromised } \\
\text { persons }{ }^{*}\end{array}$ & $\begin{array}{l}\text { Same for nonimmunocompromised persons } \\
\text { and children }\end{array}$ & 60 days $^{3}$ \\
\hline \multicolumn{3}{|c|}{$\begin{array}{l}\text { * Cutaneous anthrax with signs of systemic involvement, extensive edema, or lesions on the head or neck require } \\
\text { intravenous therapy, and a multidrug approach is recommended. Table } 1 \text {. } \\
\text { † Ciprofloxacin or doxycycline should be considered first-line therapy. Amoxicillin } 500 \text { mg po TID for adults or } 80 \\
\text { mg/kg/day divided every } 8 \text { hours for children is an option for completion of therapy after clinical improvement. } \\
\text { Oral amoxicillin dose is based on the need to achieve appropriate minimum inhibitory concentration levels. } \\
\text { 'Previous guidelines have suggested treating cutaneous anthrax for } 7-10 \text { days, but } 60 \text { days is recommended in the } \\
\text { setting of this attack, given the likelihood of exposure to aerosolized } B \text {. anthracis }(6) \text {. } \\
\text { 1 The American Academy of Pediatrics recommends treatment of young children with tetracyclines for serious } \\
\text { infections (e.g., Rocky Mountain spotted fever). } \\
\text { ** Although tetracyclines or ciprofloxacin are not recommended during pregnancy, their use may be indicated for } \\
\text { life-threatening illness. Adverse effects on developing teeth and bones are dose related; therefore, doxycycline } \\
\text { might be used for a short time (7-14 days) before } 6 \text { months of gestation. }\end{array}$} \\
\hline
\end{tabular}

Source: CDC 2001

\section{REFERENCES}

CDC. Update: Investigation of bioterrorism-related anthrax and interim guidelines for exposure management and antimicrobial therapy. 2001. MMWR. 2001;50(42):889-919.

Johns Hopkins Antibiotics (ABX) Guide. Available at: http://hopkins-abxguide.org/. Updated May 9, 2009. Accessed July 5, 2009.

Mayer TA, Bersoff-Matcha S, Murphy C, Earls J, Harper S, Pauze D, Nguyen M, Rosenthal J, Cerva, Jr D, Druckenbrod G, Hanfling D, Fatteh N, Nayyar A, Berman EL. Clinical presentation of inhalational anthrax following bioterrorism exposure: report of 2 surviving patients. JAMA. 2001;286:2549-53.

\section{WHAT IS THE ANTHRAX VACCINE?}

Scientists consider anthrax vaccine "inactivated" because the vaccine does not contain live bacteria. The vaccine is made from a strain of the anthrax bacteria that cannot cause anthrax infection. The main ingredient of the vaccine 
is a protein called "protective antigen" or PA, which helps the body make antibodies that neutralize the anthrax germ's ability to cause disease.

The anthrax vaccine can be used in two ways: to prevent infections of anthrax in people who are at high risk of exposure (e.g. veterinarians, specialized laboratory workers, military personnel) and as part of a treatment regimen following potential exposure to anthrax spores. The combination of 60 days antibiotics plus 3 doses of vaccine used in post exposure prophylaxis are very effective in preventing anthrax disease from occurring after an exposure.

Since the original license for production of the anthrax vaccine was issued in 1970, over 8 million immunizations have been administered to more than million individuals (Bienek 2009).

\section{REFERENCES}

Anthrax Vaccine Immunization Program. U.S. Department of Defense. Available at: http://www.Anthrax.osd.mil. Accessed July 23, 2009.

Bienek DR, Loomis LJ, Biagini RE. The anthrax vaccine: No new tricks for an old dog. Human Vaccines. 2009;5(3):184-189.

\section{WHAT IS THE PROTOCOL FOR ANTHRAX VACCINATION?}

The primary immunization series consists of three 0.5 milliliter injections given at day 0 , weeks 2 and 4 . An additional three doses of vaccine at months 6,12 , and 18 can be given to maintain efficacy. Following the initial six doses, annual 0.5 milliliter booster injections of the vaccine are recommended to maintain immunity to the disease if there is some risk of continued exposure.

The anthrax vaccine was originally developed for pre-exposure prevention of anthrax. While highly effective in post-exposure prevention when combined with antibiotics, the vaccine is currently not licensed for post-exposure use in a 3-dose regimen. A post-exposure treatment program would therefore be conducted under an Emergency Use Authorization (EUA) approval from the FDA after a declaration of emergency from the Secretary of Health and Human Services after extensive consultation with the NIH and CDC. Persons must be informed of "significant known and potential benefits and risks" and have the right to refuse the vaccine for themselves, their children or others without the capacity to consent (Nightingale 2007).

In December 2008, the FDA approved a new 5-dose regimen of the anthrax vaccine for routine immunization of workers requiring pre-exposure prophylaxis (e.g. military personal, high risk laboratory workers). The 5-dose regimen drops the dose at week 2 and involves a change in the route of administration from subcutaneous to intramuscular. The new regimen appears to be associated with a lower incidence of local effects (Marano 2008); however the 6-dose regimen is still recommended for post-exposure prophylaxis, when earlier development of antibody resistance may be particularly important. 


\section{REFERENCES}

Anthrax Vaccine Immunization Program. U.S. Department of Defense. Available at: http://www.Anthrax.osd.mil. Accessed August 3, 2009.

CDC. Anthrax Q\&A: Vaccination. Available at: http://www.bt.cdc.gov/agent/anthrax/faq/vaccination.asp. Updated February 2, 2009. Accessed August 3, 2009.

FDA. Approval Letter from FDA to Emergent Solutions regarding change in dosage schedule and change in route of administration for BioThrax ${ }^{\circledR}$ vaccine. December 11, 2008. Available at:

http://www.fda.gov/BiologicsBloodVaccines/Vaccines/ApprovedProducts/ucm124462.htm.

Marano N, Plikaytis BD, Martin SW, Rose C, Semenova VA, et al. Effects of a reduced dose schedule and intramuscular administration of anthrax vaccine adsorbed on immunogenicity and safety at 7 months: a randomized trial. JAMA. 2008;300(13):1532-43.

Nightingale SL, Prasher JM, Simonson S. Emergency Use Authorization (EUA) to Enable Use of Needed Products in Civilian and Military Emergencies, United States. Emerging Infectious Diseases. 2007;13(7):1046-51.

\section{WHEN MUST TREATMENT BEGIN FOR ANTHRAX?}

Antibiotic treatment and the vaccine regimen should begin as soon as possible after exposure to aerosolized Bacillus anthracis spores. The longer treatment is delayed, the greater the risk of death. Anthrax vaccine should be offered within 10 days of exposure. Starting oral antibiotics within 24 to 48 hours of exposure to anthrax spores is strongly recommended.

In the 2001 anthrax mail outbreak, six of the ten people infected with inhalational anthrax that survived received treatment with antibiotics active against Bacillus anthracis on same day as exposure. Fatalities occurred in patients who had severe disease by the time they first received antibiotics (Jernigan 2001). No individuals that received post-exposure prophylaxis with oral medications developed anthrax in the 2001 mail outbreak.

\section{REFERENCE}

Jernigan JA, Stephens DS, Ashford DA, Omenaca C, Topiel MS, Galbraith M, et al. Bioterrorism-related inhalational anthrax: the first 10 cases reported in the United States. Emerging Infectious Diseases. 2001;7(6):933-44.

\section{WHY ARE 60 DAYS OF ANTIBIOTIC TREATMENT RECOMMENDED?}

Anthrax spores take an average of 7 days to develop into the harmful form of the bacteria inside the body, but can take longer. The 60 day course of treatment is recommended because studies in primates have demonstrated that anthrax spores can remain viable in the body for months before germinating and causing the disease (Kelly 1992 , Kao 2006). At least 60 days was required for effective prevention. 
Non-compliance with recommended treatment procedures can pose a serious health risk to those exposed to anthrax disease. The extent to which one is protected prior to completion of the full immunization and antibiotic schedule is unknown. If treatment stops too soon, the drug may not inactivate all the bacterial spores. The individual may become sick again, and the remaining bacteria may become resistant to the antibiotic taken.

\section{REFERENCES}

Kao LM, Bush K, Barnewall R, Estep J, Thalacker FW, Olson PH, Drusano GL, Minton N, Chien S, Hemeryck A, Kelley MF. Pharmacokinetic Considerations and Efficacy of Levofloxacin in an Inhalational Anthrax (Postexposure) Rhesus Monkey Mode. Antimicrobial Agents and Chemotherapy. 2006; 50(11):3535-42.

Kelly DJ, Chulay JD, Mikesell P, Friedlander AM. Serum Concentrations of Penicillin, Doxycycline, and Ciprofloxacin during Prolonged Therapy in Rhesus Monkeys. Journal of Infectious Diseases. 1992;166:1184-87.

Vietri NJ, Purcell BK, Lawler JV, Leffel EK, Rico P, Gamble CS, Twenhafel NA, Ivins BE, Heine HS, Sheeler R, Wright $\mathrm{ME}$, Friedlander AM. Short-course post-exposure antibiotic prophylaxis combined with vaccination protects against experimental inhalational anthrax. Proceedings of the National Academy of Sciences. 2006;103:7813-16.

SHOULD CHILDREN BE OFFERED ANTIBIOTICS AND VACCINATION IF ANTHRAX EXPOSURE IS SUSPECTED?

Children with known or suspected exposure to anthrax spores should be offered antibiotics, and may be given anthrax vaccine depending on the specific circumstances of the event and exposure.

The recommended antibiotic treatment for children is ciprofloxacin. Doxycycline is not generally approved for treating patients under 8 years old; however, due to the seriousness of anthrax disease, the American Academy of Pediatrics recommends doxycycline if antibiotic susceptibility testing, exhaustion of drug supplies, or adverse reactions preclude use of ciprofloxacin. See dosage table for more information.

Use of anthrax vaccine in pediatric populations in a post-event setting with a high risk of exposure is likely to be more helpful than harmful. Anthrax vaccine is not licensed for use in pediatric populations and has not been studied in children; however, the vaccine is probably safe and efficacious in children, based on experience with other inactive vaccines, such as tetanus (Inglesby 2002). The FDA has an Emergency Use Authorization (EUA) to use anthrax vaccine in children that requires parents to sign a form (Nightingale 2007).

\section{REFERENCES}

CDC. Children and Anthrax: A Fact Sheet for Parents. Available at: http://www.bt.cdc.gov/agent/Anthrax/parentsfactsheet.asp. Updated November 8, 2001. Accessed August 3, 2009.

Inglesby TV, O'Toole T, Henderson DA, et al, for the Working Group on Civilian Biodefense. Anthrax as a biological weapon: updated recommendations for management. JAMA. 2002;287(17):2236-52. 
Nightingale SL, Prasher JM, Simonson S. Emergency Use Authorization (EUA) to Enable Use of Needed Products in Civilian and Military Emergencies, United States. Emerging Infectious Diseases. 2007;13(7):1046-51.

\section{SHOULD IMMUNOCOMPROMISED PERSONS RECEIVE ANTIBIOTICS AND VACCINATION IF ANTHRAX EXPOSURE IS SUSPECTED?}

Yes. The 60-day antibiotics and 6-dose anthrax vaccine regimen recommended for adults is also recommended for immunocompromised persons. Because of the seriousness of anthrax disease, medical experts believe treating immunocompromised persons with antibiotics and the vaccine minimizes the chances of developing anthrax in those that are more susceptible to infection

The anthrax vaccine is an inactivated or killed vaccine, similar to a tetanus or flu shot. The vaccine can be given to any person regardless of immune status.

\section{REFERENCE}

Inglesby TV, Henderson DA, Bartlett JG, et al. Anthrax as a biological weapon: medical and public health management. JAMA. 1999;281(18):1735-45.

\section{SHOULD PREGNANT OR BREASTFEEDING WOMEN RECEIVE ANTIBIOTICS AND VACCINATION} IF ANTHRAX EXPOSURE IS SUSPECTED?

Yes. Pregnant and breastfeeding women with known or suspected exposure to anthrax spores should be offered 60 days of antibiotics and the anthrax vaccine.

Ciprofloxacin works well to prevent anthrax and is not likely to cause major problems for the fetus, but not enough studies have been done with pregnant women who have taken ciprofloxacin to say that there is no risk to the fetus (Friedman 2000, CDC 2005).

Doctors are more certain that amoxicillin is safe for the fetus, but amoxicillin may not always work against anthrax. Before prescribing amoxicillin, health care providers will want to make sure that the strain of anthrax to which the individual was exposed can be treated by amoxicillin (CDC 2001a, 2005).

Doxycycline can sometimes cause problems for the teeth and bones of the fetus. The drug should only be used when there are concerns associated with use of either ciprofloxacin or amoxicillin (CDC 2005).

Ciprofloxacin, amoxicillin, and doxycycline are each excreted in breast milk. Both ciprofloxacin and amoxicillin are considered "usually compatible with breastfeeding" by the American Academy of Pediatrics. Short-term use of doxycycline by lactating women is not necessarily contraindicated, however, the effects of prolonged exposure to doxycycline in breast milk are unknown (AAP 2001). Because all of these drugs are excreted in breastmilk, a breastfeeding woman should be treated or given prophylaxis with the same antibiotic as her infant based on what is most safe and effective for the infant. 
It is not known whether anthrax vaccine is excreted in human milk; however anthrax vaccine must be injected to provide immunity to infection. Vaccinating breastfeeding women is considered less harmful than if the individuals become infected with a disease that this vaccine could prevent (Wright 2008).

\section{REFERENCES}

AAP. Committee on Drugs, American Academy of Pediatrics. The transfer of drugs and other chemicals into human milk. Pediatrics. 2001;108(3):776-89.

CDC - National Center on Birth Defects and Developmental Disabilities. Guidelines for Pregnant Women Who Have Been Exposed to Anthrax But Do Not Have Symptoms. Available at: http://www.cdc.gov/ncbddd/bd/anthrax.htm. Updated October 5, 2005. Accessed July 5, 2009.

CDC. Update: Investigation of bioterrorism-related anthrax and interim guidelines for exposure management and antimicrobial therapy. MMWR. 2001;50(42);909-19.

CDC. Updated recommendations for antimicrobial prophylaxis among asymptomatic pregnant women after exposure to Bacillus anthracis. MMWR. 2001a;50(43):960.

FDA. Doxycycline (Vibramycin, Monodox, Doryx, Doxy, Atridox, Periodox, Vibra-Tabs) Use by Pregnant and Lactating Women. Available at:

http://www.fda.gov/Drugs/EmergencyPreparedness/BioterrorismandDrugPreparedness/ucm131011.htm. Updated April 30, 2009. Accessed July 5, 2009.

FDA. CIPRO (Ciprofloxacin) Use by Pregnant and Lactating Women. Available at: http://www.fda.gov/Drugs/EmergencyPreparedness/BioterrorismandDrugPreparedness/ucm130712.htm. Updated April 30, 2009. Accessed July 5, 2009.

FDA. Amoxicillin (Amoxil, Larotid, Trimox, Wymox) Use by Pregnant and Lactating Women. Available at: http://www.fda.gov/Drugs/EmergencyPreparedness/BioterrorismandDrugPreparedness/ucm072124.htm\#4. Updated April 30, 2009. Accessed July 5, 2009.

Friedman JM and Polifka JE. Teratogenic Effects of Drugs. A Resource for Clinicians (TERIS). Baltimore, MD: The Johns Hopkins University Press; 2000:149-95.

Inglesby TV, Henderson DA, Bartlett JG, et al. Anthrax as a biological weapon: medical and public health management. JAMA. 1999;281(18):1735-45.

Loebstein R, Addis A, Ho E, et al. Pregnancy outcome following gestational exposure to fluoroquinolones: a multicenter prospective controlled study. Antimicrobial Agents Chemotherapy. 1998;42(6):1336-9.

Wilton LV, Pearce GL, Mann RD. A comparison of ciprofloxacin, norfloxacin, ofloxacin, azithromycin and cefixime examined by observational cohort studies. British Journal of Clinical Pharmacology. 1996;41:277-84.

Wright JB. Recommendations for Anthrax Vaccination of Pregnant and Breastfeeding Women. Presentation at: ACIP Anthrax Vaccine Work Group; October 22, 2008; Atlanta, GA. 


\section{SHOULD INDIVIDUALS THAT HAVE RECEIVED THE ANTHRAX VACCINE PRIOR TO POTENTIAL EXPOSURE BE TREATED WITH ORAL ANTIBIOTICS?}

Yes, individuals who have been partially or fully vaccinated should receive at least a 60-day course of antibiotics, complete the 6-dose vaccination regimen, and continue to receive annual boosters while working in a risk environment. They should be given antibiotics plus a vaccine booster.

Little data exists about the effectiveness of post-exposure antimicrobial treatment among exposed persons who have been partially or fully vaccinated. In the only human clinical trial of anthrax vaccine, cases occurred among participants who had received less than 4 doses (Pittman 2002).

\section{REFERENCES}

CDC. Occupational health guidelines for remediation workers at Bacillus anthracis--contaminated sites-United States, 2001-2002. MMWR. 2002;51:786-9.

Pittman PR, Kim-Ahn G, Pifat DY, et al. Anthrax vaccine: immunogenicity and safety of a dose-reduction, routechange comparison study in humans. Vaccine. 2002;20:1412-20.

\section{WHO SHOULD GET ANTHRAX VACCINE PRIOR TO EXPOSURE?}

The Department of Defense has mandated all U.S. military active- and reserve-duty personnel going to high risk overseas duty stations receive pre-exposure vaccination to prevent disease from anthrax exposure to biological weapons.

According to the Advisory Committee on Immunization Practices (ACIP) other groups for which pre-exposure anthrax vaccination is recommended include:

- People 18 to 65 years of age potentially exposed to large amounts of Bacillus anthracis bacteria on the job, such as laboratory workers.

- Possibly for high-risk persons handling potentially infected items in areas with a high incidence of anthrax cases (e.g. veterinarians).

- Persons who come in contact in the workplace with imported animal hides, furs, bone meal, wool, animal hair, or bristles, when standards and restrictions are insufficient to prevent exposure to anthrax spores.

- Those conducting activities with a high potential for Bacillus anthracis aerosol production.

\section{REFERENCES}

CDC. Use of Anthrax Vaccine in the United States: Recommendations of the Advisory Committee on Immunization Practices (ACIP). MMWR. 2000;49(RR15):1-20. 
CDC. Use of anthrax vaccine in response to terrorism: supplemental recommendations of the Advisory Committee on Immunization Practices. MMWR. 2002;51:1024-6.

Anthrax Vaccine Immunization Program. U.S. Department of Defense. Available at: http://www.Anthrax.osd.mil. Accessed July 23, 2009.

\section{SHOULD FIRST RESPONDERS BE VACCINATED FOR BIOTERRORISM PREPAREDNESS?}

Emergency and other responders, including police departments, fire departments, hazardous material units, the National Guard and others, are not recommended by the Advisory Committee on Immunization Practices (ACIP) for routine pre-event anthrax vaccination. However, because the risk of exposure for first responders to anthrax is not zero, first responder units may choose to offer their workers pre-event vaccination on a voluntary basis. Some first responder groups have shown an interest in an anthrax vaccination program.

\section{REFERENCES}

CDC. Use of anthrax vaccine in the United States: Recommendations of the Advisory Committee on Immunization Practices (ACIP). MMWR 2000; 49(RR-15):1-20.

Wright JB. Recommendations for the Pre-Event Use of Anthrax Vaccine Among First Responders. Presentation on behalf of the ACIP Anthrax Vaccine Work Group, October 23, 2008. Atlanta, GA.

\section{ARE THERE ANY PROMISING NEW TREATMENTS FOR ANTHRAX DISEASE UNDER DEVELOPMENT?}

One of the challenges associated with long-term antibiotic use is that negative side effects can occur and therefore treatment is often discontinued. Discontinuing antibiotic treatment presents a serious threat of infection to people exposed to anthrax as the spores can persist in the body for months before germinating and causing the disease.

Current research on alternative antibiotic therapy for anthrax infection is examining the effectiveness of a new long-acting antibiotic, Dalbavancin. Research in mice shows that a single dose of the long-acting antibiotic Dalbavancin protects against anthrax for up to 15 days. (Klinman and Tross 2009).

Results show that significant protection is achieved by delivering a single dose of Dalbavancin combined with a rapidly immunogenic vaccine/adjuvant any time within 3 days of anthrax exposure (Klinman and Tross 2009).

Vaccine research has also looked at the inclusion of an adjuvant in the formulation of the licensed anthrax vaccine BioThrax ${ }^{\circledR}$ AVA to increase immune response and the ability to use less antigen per dose or fewer doses to achieve protection. One promising group of adjuvants that is being investigated with a variety of vaccines and shown to be effective are oligonucleotide proteins (Mili Gua 2008).

Future vaccine research efforts include developing a recombinant anthrax vaccine and anthrax monoclonal antibodies to block the anthrax toxin(s). It is projected that the next-generation vaccine will elicit a markedly 
increased anti-anthrax immune response within a shorter time period and consequently will enable easier inoculations of individuals working within high-risk areas.

Significant progress is being made in the commercial development of monoclonal and polyclonal antibodies that function as potent neutralizers of anthrax toxins. Several new products have completed Phase I clinical trials and are scheduled for addition to the National Strategic Stockpile. (Schneemann 2009). One of these new drugs, ABthrax or raxibacumab, specifically targets the toxins once they enter the bloodstream and could be used if antibiotic treatment was ineffective (Migone 2009).

ABthrax is a monoclonal antibody designed to attack and neutralize the toxin. Animal studies have shown ABthrax provides $100 \%$ protection if given before inhaling anthrax. One dose after exposure improves an animal's survival odds by 64\%, even when administered after animals were already showing clinical symptoms as a result of inhalation exposure to massively lethal doses of anthrax spores. Human Genome Sciences, Inc (HGS), the developer of ABthrax, has completed safety studies of ABthrax in more than 400 human volunteers. The clinical results to date suggest that ABthrax was generally safe and well tolerated. In 2009, HGS announced the first delivery of 20,000 doses of ABthrax to the United States Department of Defense (HGS 2009). The U.S. Food and Drug Administration has not yet licensed the drug.

\section{REFERENCES}

Comer JE, Peterson JW. Anthrax. In: Barrett ADT, Stanberry LR, eds. Vaccines for Biodefense and Emerging and Neglected Diseases. Academic Press;2009:787-806.

Human Genome Sciences website. Available at: http://www.hgsi.com/raxibacumab.html. Accessed August 3, 2009.

Klinman DM, Tross D. A single-dose combination therapy that both prevents and treats anthrax infection. Vaccine. 2009;27(12):1811-5.

Migone T, Subramanian GM, Bolmer SD, et.al. Raxibacumab for the treatment of inhalational anthrax. New England Journal of Medicine. 2009;361:135-44.

Mili Gua PM, Hinea W, Jacksona J, Giria L, Nabors GS. Increased potency of BioThrax ${ }^{\circledR}$ anthrax vaccine with the addition of the C-class CpG oligonucleotide adjuvant CPG 10109. Vaccine. 2007;25(3):526-34.

Pettineo C, Aitchison R, Leikin SM, Vogel SN, Leikin JB. Biological and Chemical Weapons of Mass Destruction: Updated Clinical Therapeutic Countermeasures Since 2003. American Journal of Therapeutics. 2009;16(1):35-43.

Schneemann A, Manchester M. Anti-toxin antibodies in prophylaxis and treatment of inhalation anthrax. Future Microbiology. 2009;4(1):35-43. 


\section{EFFICACY OF RECOMMENDED MEDICATIONS}

\section{HOW EFFECTIVE IS THE RECOMMENDED COMBINED ANTIBIOTIC-VACCINE TREATMENT?}

Combining prompt antibiotic prophylaxis and anthrax vaccination offers the best means of protecting individuals against inhalational anthrax. In a 2006 study, two groups of rhesus monkeys that were exposed to lethal levels of aerosolized anthrax spores. Both groups were given the antibiotic ciprofloxacin twice daily for 14 days, beginning 1-2 hours after exposure. One group also received three doses of anthrax vaccine after exposure. In the ciprofloxacin-only group, four of nine monkeys (44\%) survived. In contrast, all 10 monkeys that received 14 days of antibiotic plus anthrax vaccine survived. Thus post-exposure vaccination enhanced the protection afforded by 14 days of antibiotic prophylaxis alone and completely protected animals against inhalational anthrax.

\section{REFERENCES}

Vietri NJ, Purcell BK, Lawler JV, Leffel EK, Rico p, Gamble CS, Twenhafel NA, Ivins BE, Heine HS, Sheeler R, Wright $\mathrm{ME}$, Friedlander AM. Short-course post-exposure antibiotic prophylaxis combined with vaccination protects against experimental inhalational anthrax. Proceedings of the National Academy of Sciences (PNAS). 2006;13(20):7813-16.

\section{HOW EFFECTIVE IS ANTIBIOTIC-ONLY TREATMENT FOR ANTHRAX?}

A systematic review of inhalation anthrax cases identified between 1900 and 2005 reported the following observations with regard to treatment (Holty 2006):

- When treated with only antibiotics, people with cutaneous anthrax are usually cured. Less than $1 \%$ of people who are treated die; up to $20 \%$ of those who do not get treatment may die.

- People with second-stage inhalation anthrax have a poor outcome, even with antibiotic therapy. About $60 \%$ of the patients in the U.S. 2001 outbreak who received early antibiotic therapy survived. Only $25 \%$ who received antibiotics $>4.7$ days after illness onset survived. Overall fatality estimates are incomplete but the rate is approximately $75 \%$ for those with inhalational anthrax and delays in therapy.

- The prognosis of gastrointestinal anthrax is also poor. Between 25 and $60 \%$ of people may die from this disease. The role of early antibiotic treatment for this form of anthrax has not been defined.

A concern is the possibility that a future biological attack could involve anthrax strains that are resistant to currently recommended antibiotics. Antibiotic resistance can also occur when administering antibiotics to large numbers of people (Schneeman 2009). 


\section{REFERENCES}

Holty JEC, Kim RY, Bravata DM. Anthrax: a systemic review of atypical presentations. Annals of Emergency Medicine. 2006;48:200.

Schneeman A, Manchester M. Anti-toxin antibodies in prophylaxis and treatment of inhalation anthrax. Future Microbiology. 2009;4(1):35-43.

\section{HOW EFFECTIVE IS THE ANTHRAX VACCINE?}

The National Academy of Sciences' Institute of Medicine in 2000 convened the "Committee to Assess the Safety and Efficacy of the Anthrax Vaccine" to examine the safety and efficacy of the licensed AVA vaccine. The Committee concluded that available evidence from studies with humans and animals, coupled with reasonable assumptions, shows that AVA as licensed is an effective vaccine for the protection of humans against anthrax toxicity from all known strains of Bacillus anthracis, as well as from any potential bioengineered strains anthrax (Joellenbeck 2002).

The Institute of Medicine (2002) concluded that the vaccine is "acceptably safe and effective" in protecting humans against anthrax toxicity from all known strains of Bacillus anthracis, as well as from any potential bioengineered strains. However, reliance on the vaccine alone after exposure is insufficient, as some protection is needed during the time required for an immune response to develop.

The data used to evaluate the efficacy of AVA come from three sources. Studies with wool mill workers tested the efficacy of AVA and a related vaccine against occupational exposures to anthrax spores. Serological studies with humans tested the ability of AVA to develop antibodies to protective antigen (PA), an indication of an immune response to the vaccine. Studies with animals tested the efficacy of the vaccine in protecting the animals from inhalational exposure to anthrax spores (Joellenbeck 2002).

The only study of the efficacy of the vaccine for humans was published in 1962 and the study examined the efficacy of an earlier formulation of the AVA. The study was carried out in mill workers that processed raw, imported goat hair, which was typically contaminated with anthrax spores. In this controlled study, 379 employees received the vaccine, 414 received the placebo, and 340 received neither the vaccine nor the placebo. Over the course of the study, 26 cases of anthrax occurred, 21 of which were cutaneous anthrax and 5 were cases of inhalational anthrax. Of the 26 cases, 3 occurred among vaccine recipients ( 2 incomplete inoculees and 1 complete), 17 occurred among individuals in the placebo group ( 2 incomplete inoculees and 15 complete), and 6 cases occurred in individuals who were not inoculated with the vaccine or the placebo. Very few the cases of inhalational anthrax occurred in persons who had received the vaccine. The overall effectiveness of the vaccine against anthrax infection was $92.5 \%$ (Brachman 1962).

Findings from the immune response studies indicate that AVA administered by the licensed dosing schedule, as well as by schedules that omit the dose administered at 2 weeks as originally recommended, generated antibody response rates of 96 to 100 percent. (Joellenbeck 2002)

Results from several animal studies provide additional evidence that the vaccine protects against anthrax with hundreds of times the lethal dose of anthrax by inhalation. Laboratory experiments indicate that AVA provides 
effective protection against inhalational challenge in rabbits and monkeys, the animal models in which the disease is most reflective of the disease in humans. When monkeys were exposed experimentally to doses of up to about 900 times the amount expected to kill half of the animals, 88 to 100 percent of the animals were protected (Fellows 2001; Ivins 1996, 1998; Pitt 2001).

\section{REFERENCES}

Brachman PS, Gold H, Plotkin SA, Fekety FR, Werrin M, Ingraham NR. Field evaluation of a human anthrax vaccine. American Journal of Public Health. 1962;52(4):632-45.

Fellows PF, Linscott MK, Ivins BE, Pitt ML, Rossi CA, Gibbs PH, Friedlander AM. Efficacy of a human anthrax vaccine in guinea pigs, rabbits, and rhesus macaques against challenge by Bacillus anthracis isolates of diverse geographical origin. Vaccine. 2001;19(23-24):3241-47.

Ivins BE, Fellows PF, Pitt MLM, Estep JE, Welkos SL, Worsham PL, Friedlander AM. Efficacy of a standard human anthrax vaccine against Bacillus anthracis aerosol spore challenge in rhesus monkeys. Salisbury Medical Bulletin. 1996;87(Suppl):125-126.

Ivins BE, Pitt ML, Fellows PF, Farchaus JW, Benner GE, Waag DM, Little SF, Anderson GW Jr, Gibbs PH, Friedlander AM. Comparative efficacy of experimental anthrax vaccine candidates against inhalation anthrax in rhesus macaques. Vaccine. 1998;16(11-12):1141-48.

Joellenbeck LM, Zwanziger LL, Durch JS, Strom BL, eds, The Anthrax Vaccine: Is It Safe? Does It Work? Washington, D.C.: National Academy Press; 2002.

Pitt MLM. Animal models for anthrax vaccine efficacy. Presentation at: Institute of Medicine Committee to Assess the Safety and Efficacy of the Anthrax Vaccine; April 17, 2001; Washington, D.C.

\section{SAFETY AND POTENTIAL REACTIONS TO MEDICATIONS}

\section{HOW SAFE IS IT TO TAKE THESE ANTIBIOTICS FOR LONG PERIODS OF TIME?}

Long-term use of antibiotics appears safe for adults and children if needed for post-exposure anthrax prevention. A recent study of approximately 100,000 patients showed no increase in risk of adverse events from long-term use of ciprofloxacin, doxycycline, and amoxicillin (Meropol 2008). Young adults have been taking doxycycline for long periods of time to treat acne, and ciprofloxacin has been used in children for extended periods to treat cystic fibrosis. However, individuals taking these drugs may experience some of the side effects common with antibiotic use, most commonly nausea, upset stomach and diarrhea. With ciprofloxacin, a case of kidney damage was reported in an individual taking that drug long term during the 2001 anthrax outbreak.

There is an FDA Alert regarding an increased risk of tendonitis from long term use of ciprofloxacin, levofloxacin, and other fluoroquinolones. Tendon rupture can happen while taking or after completing a cycle of these antibiotics. Ruptures have happened up to several months after patients have finished taking their 
fluoroquinolone. Medical professionals should be aware that they may be seeing increased occurrences of tendon ruptures among persons taking these antibiotics after an anthrax event.

\section{REFERENCES}

Meropol SB, Chan KA, Chen Z, Finkelstein JA, Hennessy S, Lautenbach E, Platt R, Schech SD, Shatin D, Metlay JP. Adverse events associated with prolonged antibiotic use. Pharmacoepidemiology Drug Safety. 2008;17(5):523-32.

\section{WHAT ADVERSE REACTIONS ARE ASSOCIATED WITH THE RECOMMENDED ANTIBIOTICS?}

All of the recommended antibiotics for preventing and treating anthrax infection are associated with some side effects. Side effects are usually mild, but can become bothersome.

Ciprofloxacin: Common side effects include an upset stomach, vomiting, diarrhea, fatigue, dizziness or headache. Less common side effects include pain in arms or legs, tendon rupture, changes in vision, restlessness, ringing in the ears, or mental changes. Severe allergic reactions are very rare. Signs of an allergic reaction include rash, itching, swelling of the tongue, hands or feet, fever, or trouble breathing. (CDC 2005; FDA 2009)

Doxycycline: Common side effects include an upset stomach, vomiting, diarrhea, vaginal yeast infection, and increased sensitivity of skin to sunlight. Less common side but more serious side effects include liver damage (symptoms include dark urine, yellowing of the eyes or skin, abdominal pain, loss of appetite, nausea, vomiting), irritation of the esophagus, blood problems (symptoms are unusual bleeding or bruising), life-threatening allergic reactions (symptoms are trouble breathing, hives, closing of throat, and swelling of lips, tongue or face). (FDA 2009)

A study of specific adverse reactions associated with the recommended 60-day antibiotic cycle for prevention and treatment of anthrax was conducted after the 2001 anthrax exposures. The study involved 5,343 people from the six U.S. sites that reported taking at least one dose of antibiotics to prevent inhalational anthrax. (Shepard 2002)

- Approximately 57\% reported adverse events during the first 60 days of antimicrobial prophylaxis use. Among persons reporting adverse events, $41 \%$ graded them as none/mild, $45 \%$ as moderate, and $14 \%$ graded them as severe.

- The most commonly reported symptoms were gastrointestinal (44\%, including nausea or vomiting, diarrhea or stomach pain, heartburn, and pain with swallowing) and neurologic (33\%, including headache, dizziness, lightheadedness, fainting, and seizure).

- $43 \%$ of those who started antibiotic treatment stated that they discontinued antibiotic therapy because of adverse events. There were no substantial differences in rates of adverse events associated with ciprofloxacin compared with doxycycline.

- Of 3,374 persons participating in 30-day follow-up, four persons had severe reactions in which antimicrobial prophylaxis was judged to be the definite or probable cause. Two persons developed a diffuse rash and systemic symptoms; the remaining two involved swelling of the face and neck. One patient was briefly hospitalized. All four recovered. 


\section{REFERENCES}

CDC. Anthrax Q \& A: Preventive Therapy. Available at: http://www.bt.cdc.gov/agent/Anthrax/faq/preventive.asp. Updated March 25, 2005. Accessed July 24, 2009.

FDA. Questions and Answers for Consumers on Doxycycline. Available at:

http://www.fda.gov/Drugs/EmergencyPreparedness/BioterrorismandDrugPreparedness/ucm131012.htm.

Updated May 23, 2009. Accessed July 24, 2009.

Shepard CW, Soriano-Gabarro-Soriano M, Zell ER, Hayslett J, Lukacs S, Goldstein S, et al. Antimicrobial postexposure prophylaxis for anthrax: adverse events and adherence. Emerging Infectious Disease. 2002; 8(10):112432. Available at: http://www.cdc.gov/ncidod/EID/vol8no10/02-0349.htm.

\section{HOW SAFE IS THE ANTHRAX VACCINE?}

In October 2000, the Institute of Medicine convened the "Committee to Assess the Safety and Efficacy of the Anthrax Vaccine." After examining data from numerous case reports and epidemiologic studies, the Committee to Assess the Safety and Efficacy of the Anthrax Vaccine (2002) concluded that Anthrax Vaccine is reasonably safe.

The review indicates that following vaccination, recipients commonly experience some local events (e.g. arm motion limitation, redness, itching, swelling, or tenderness at the injection site), while a smaller number of vaccine recipients experience some systemic events (e.g. fever and malaise). These immediate reactions, and the rates at which they occur, are comparable to those observed with other vaccines regularly administered to adults. The committee found no evidence that vaccine recipients face an increased risk of experiencing life-threatening or permanently disabling adverse events immediately after receiving AVA, when compared with the general population. The committee did not find any convincing evidence that vaccine recipients faced an elevated risk of developing adverse health effects over the longer term, although data was limited in this regard (as they are for all vaccines) (Joellenbeck 2002).

\section{REFERENCES}

Joellenbeck LM, Zwanziger LL, Durch JS, Strom BL, eds, The Anthrax Vaccine: Is It Safe? Does It Work? Washington, DC: National Academy Press; 2002.

\section{WHAT SIDE EFFECTS ARE ASSOCIATED WITH THE ANTHRAX VACCINE?}

Mild local reactions occur in 30\% of recipients and consist of slight tenderness and redness at the injection site. Severe local reactions are infrequent and consist of extensive swelling of the forearm in addition to the local reaction. Systemic reactions occur in fewer than $0.2 \%$ of recipients. The non-serious local reactions are greater among women.

Mild local reactions to the anthrax vaccine are common and include: 
- Soreness, redness, or itching where the shot was given (about 1 out of 10 men, about 1 out of 6 women)

- A lump where the shot was given (about 1 person out of 2)

- Muscle aches or joint aches (about 1 person out of 5)

- Headaches (about 1 person out of 5)

- Fatigue (about 1 out of 15 men, about 1 out of 6 women)

- Chills or fever (about 1 person out of 20)

- $\quad$ Nausea (about 1 person out of 20)

More severe local reactions are infrequent and can include a large areas of redness where the shot was given (up to I person out of 20).

Severe systemic problems are very rare and can include serious allergic reaction (less than once in 100,000 doses).

\section{REFERENCES}

CDC. Anthrax Q\&A: Vaccination. Available at: http://www.bt.cdc.gov/agent/anthrax/faq/vaccination.asp. Updated February 2, 2009. Accessed July 24, 2009.

CDC - National Immunization Program. Anthrax Vaccine Information Statement (VIS). Available at: http://www.cdc.gov/vaccines/pubs/vis/downloads/vis-anthrax.pdf. Updated April 24, 2003. Accessed July 24, 2009.

\section{WHAT IS TREATMENT IS ADVISED FOR INDIVIDUALS WHO HAVE HAD ADVERSE REACTIONS} TO THE RECOMMENDED DRUGS?

For post-exposure prevention and treatment of anthrax infection, medical professionals will weigh the risks and benefits of antibiotic treatment based on an assessment the individuals' circumstances and the likelihood of exposure to anthrax. If individuals who are believed to have been exposed have had severe, life-threatening reactions to the recommended antibiotics (i.e. ciprofloxacin and doxycycline) in the past, alternative treatments may be recommended by a medical professional. If individuals have had a mild, non-life threatening reactions to these antibiotics, medical professionals may recommend their use if they believe the antibiotics provide less risk than contracting the disease.

\section{IS THE ANTHRAX VACCINE SAFE FOR CHILDREN, THE ELDERLY, PREGNANT WOMEN, AND THE IMMUNOCOMPROMISED?}

There is limited research on the safety of the anthrax vaccine in populations beyond those for which the vaccine is licensed. The current vaccine is licensed for pre-exposure use in healthy, non-pregnant adults, 18-65 year olds, 
who have a high likelihood of coming into contact with anthrax. The vaccine is not licensed for post-exposure use or use for these populations. Emergency Use Authorization (EUA) would be required from the FDA after a declaration of emergency from the Secretary of Health and Human Services following extensive consultation with the $\mathrm{NIH}$ and CDC. However, there is no reason to believe that the vaccine would be unsafe for children, the elderly, pregnant women or the immunocompromised (Nightingale 2007).

For post-exposure prevention and treatment of anthrax infection, medical professionals will weigh the risks and benefits of vaccination in each of these populations based on the specific circumstances of an event and exposure prior to making a recommendation on use.

According to the Advisory Committee on Immunization Practices (ACIP), the use of AVA in pediatric populations in a post-event setting with a high risk of exposure to aerosolized Bacillus anthracis spores is not contraindicated; however, its use is considered a precaution.

The FDA does have special permission for emergency use of the anthrax vaccine in children under 18.

Because it is an inactivated or killed vaccine, similar to a tetanus shot, AVA cannot cause anthrax infections although there is some risk that immunocompromised individual may not respond.

Some research has been on completed on U.S. military service women who received the vaccine while pregnant. A large observational study examined the rate of birth defects among 37,140 infants born to service women who received anthrax vaccine in pregnancy between 1998 and 2004. This study showed that the number of birth defects in children born to women who had received the vaccine during the first trimester of pregnancy was roughly the same as in a similar group of women who had received the vaccine later in the pregnancy or even after the pregnancy. While the study showed that atrial septal defect (ASD) was slightly more common in first trimester-exposed infants when compared with infants of women vaccinated outside of the first trimester and compared to unvaccinated women, the finding was not statistically significant if cases of isolated ASD in preterm infants were excluded. (Ryan 2008) In most birth defects surveillance systems, ASD in premature infants is considered normal and is generally excluded as a defect (Wright 2008).

\section{REFERENCES}

Emergent Solutions. Prescribing Information for BioThrax ${ }^{\circledR}$ (Anthrax Vaccine Adsorbed) Available at: http://www.emergentbiosolutions.com/html/biothrax.aspx. Accessed: July 5, 2009.

Nightingale SL, Prasher JM, Simonson S. Emergency Use Authorization (EUA) to Enable Use of Needed Products in Civilian and Military Emergencies, United States. Emerging Infectious Diseases. 2007;13(7):1046-51.

Ryan M, Smith TC, Sevick CJ, Honner WK, Loach RA, Moore CA, Erickson JD. Birth defects among infants born to women who received anthrax vaccine in pregnancy. American Journal of Epidemiology. 2008;168:434-42.

Wiesen AR, Littell CT. Relationship between pre-pregnancy anthrax vaccination and pregnancy and birth outcomes among US Army women. JAMA. 2002;287:1556-60. Available at: www.jama.amaassn.org/cgi/reprint/287/12/1556.pdf.

Wright JB. Recommendations for Anthrax Vaccination of Pregnant and Breastfeeding Women. Presentation at: ACIP Anthrax Vaccine Work Group; October 23, 2008; Atlanta, GA. 